\title{
Przyczynek do historii rozwoju prawa i lingua legis w Korei
}

\section{A Brief History of the Development of Law and Lingua Legis in Korea}

\author{
Emilia Wojtasik \\ INSTYTUT JĘZYKOZNAWSTWA, UNIWERSYTET IM. ADAMA MICKIEWICZA \\ AL. NIEPODLEGŁOŚCI 4, 61-874 POZNAŃ \\ ewojtasik@yahoo.com
}

\begin{abstract}
Abstrakt
Poniższy artykuł ma na celu zaprezentowanie przebiegu procesu kształtowania się prawa i jego języka na terenie Półwyspu Koreańskiego jako tła dla kierunku zapożyczeń w koreańskim języku prawa. $\mathrm{W}$ tym celu przeanalizowano nie tylko wybrane koreańskie akty prawne ze szczególnym wskazaniem głównych ich założeń, ważnych dla formujących się wówczas państw koreańskich, ale także wskazano poszczególne terminy prawa koreańskiego jak i kierunek ich pojawienia się $\mathrm{w}$ rzeczywistości prawnej państw koreańskich. Historia formowania się języka prawa na Półwyspie została przedstawiona chronologicznie i posłużyła do zaprezentowania procesu zapożyczeń w koreańskiej prawnej i prawniczej warstwie językowej jako jednej $\mathrm{z}$ cech języka prawa. Proces zapożyczania poszczególnych terminów specjalistycznych został zobrazowany przykładami z koreańskiego języka prawa.
\end{abstract}

\begin{abstract}
This article aims at describing a process of development of law and a legal language at the Korean Peninsula as a background for showing directions of word borrowings into Korean legal language. In order to achieve this assumption, not only specific Korean legal acts along with their main principles, crucial to forming up new countries in the territory, were analyzed but also some specific Korean legal terms which emerged in Korean legal reality. The history of legal language on Korean Peninsula was presented chronologically in order to present a process of
\end{abstract}


borrowing legal terms. The author presents examples of loanwords which enriched the Korean legal language.

한국어 요약
본 연구는 한반도에서 법률 그리고 그 법률에 있어서는
용어의 참조로 외래어가 온 방향의 배경을 연구한다.
이 추청을 달성하도록 한반도에서 새 국가를 건국하기
위해 한국의 법률, 그리고 그의 주요 원칙이
분석되었고 한국 법률용어 및 그의 한국 법률에
들어오는 방향도 분석되었다. 한반도에서의 법률
분야의 언어사는 연대순으로 연구되었고 법률 분야에서
쓰이는 한국어에 법률용어로써 외래어의 과정을 보여
줬다. 법률분야에서의 한국어에는 쓰이는 외래어
보기도 나와있다.

\section{Wstęp}

Język prawa w Korei rozwijał się, pozostając pod wpływem wielu czynników zewnętrznych. Do najważniejszych zaliczyć należy $\mathrm{z}$ pewnością uwarunkowania historyczne i sytuację polityczną ale także wpływy kulturowe i religijne. Czynniki te przełożyły się na stopniowe przenoszenie i adaptowanie się zwrotów i terminów specjalistycznych do koreańskich warunków. Kształtując rzeczywistość prawną, kształtowano jednocześnie język, którym tę rzeczywistość opisywano. W przypadku Korei olbrzymi wpływ miało sąsiedztwo Chin, które skutkowało przeniesieniem i stosowaniem przez bardzo długi okres bez większych zmian chińskich kodeksów cywilnego, karnego i administracyjnego (Kim Kipyo 2013:2-3).

\section{Rozwój języka prawa na Półwyspie Koreańskim}

Rozwój lingua legis w Korei wiąże się zatem ściśle z rozwojem polityki i piśmiennictwa. Olbrzymią rolę odegrały tutaj kontakty politycznohandlowe z Chinami, dzięki czemu udział terminów chińskiego pochodzenia w j. koreańskim określa się w zależności od źródeł od 60 do nawet $70 \%$ leksykonu (Sohn 2001: 87). Należy jednak pamiętać, że ze względu na konteksty historyczne oraz liczne najazdy państw ościennych, kwestie inkorporowania terminów prawnych bądź kształtowania systemu prawnego są trudne do precyzyjnego określenia. Próba chronologicznego ustalenia jest niezwykle trudna do przeprowadzenia w związku z faktem, że zapożyczenia z języka chińskiego odbywały się na przestrzeni stuleci w drodze ciągłego kontaktu i obcowania $\mathrm{z}$ językiem chińskim klasycznym, stanowiącym wówczas język literacki Korei. Jest to sytuacja analogiczna do zapożyczeń 
z języka łacińskiego przeniesionych na grunt języka polskiego na przestrzeni wieków (Rybicka-Nowacka 1973: 5). Daje się jednak zauważyć etapy rozwoju prawa oraz języka tego prawa w miarę rozwoju i konstytuowania się poszczególnych państw na Półwyspie Koreańskim a na sam koniec obecnej Republiki Korei Południowej.

\section{1 고조선 古朝鮮 [Gojoseon] - pierwsze państwo koreańskie}

Badacze historii Korei przyjmują, że pierwszym państwem na terenie Półwyspu było 고조선 古朝鮮 [Gojoseon], które trwało od mitycznego roku 2333 p.n.e. aż do 108 r. p.n.e (Rurarz 2005: 40-46). Jednocześnie przyjmuje się, że pierwszym prawem spisanym tego okresu było 팔조금법 八條禁法 [pal-jo-geum-beob], zwane również 범금팔조 犯禁八條 [beomgeum-pal-jo]. Opierało się ono na ośmiu zasadach, z których do dziś znanych jest tylko trzy, odnoszące się do regulacji kwestii życia ludzkiego oraz ciała i majątku (odpowiedzialności karnej za zabójstwo lub uszkodzenie ciała, finansowej za kradzież bądź inne przywłaszczenie rzeczy wchodzącej w skład majątku).

Późniejsze państwo Wiman Joseon 위만 조선, które istniało relatywnie krótko i zniknęło z map po najeździe chińskim wojsk dynastii Han, przekształcając się w cztery komandorie 한사군 漢四郡 [han-sa-gun], stało sięjednak miejscem, z którego na całą późniejszą Koreę rozprzestrzenił się konfucjanizm (Keum Jang Tae 2013: 15). Keum podkreśla, że „konfucjańska etyka relacji pomiędzy władcą a wasalem, oparta na humanitarności (kor. 인 in, chin. 仁 ren) i lojalności (kor. 충 chung, chin. 忠 zhong) była dominującą formą rządów podczas procesu rozwoju państwa w okresie Trzech Królestw" (2013: 16). Okres ten przyniósł także adaptację kolejnych terminów konfucjańskich, takich jak droga - 도 道 [do], prawość - 의 義 [ui], poshuszeństwo synowskie - 효 孝 [hyo], bycie wzorem - 렬 烈 [ryeol] (Keum 2013: 20), także odwaga - 용 勇 [yong] czy wiarygodność - 신 信 [sin]. Terminy, które się pojawiają m.in. $\mathrm{w}$ zasadach 팔조금법 八條禁法 [pal-jo-geum-beob] są zapisane zgodnie z ówcześnie obowiązującym na terenie Półwyspu Koreańskiego systemem zapisu w znakach chińskich.

1 Prawa te brzmią: (1) 살인자는 즉시 사형에 처한다 (相殺, 以當時償殺). (2) 남의 신체를 상해한 자는 곡물로써 보상한다(相傷, 以穀償). (3) 남의 물건을 도둑질한 자는 소유주의 집에 잡혀들어가 노예가 됨이 원칙이나, 자속(自贖:배상) 하려는 자는 50 만 전을 내놓아야 한다 (相盜, 男沒入爲其家奴, 女子爲婢, 欲自贖者人五十萬). (Tłumaczenie: „1. Morderca podlega karze śmierci. 2. Osoba, która wyrządzi szkodę ciału, spłaca tę szkodę w ziarnie. 3. Osoba, która dokona kradzieży przedmiotu [należącego do] obcej osoby, a zostanie złapana $\mathrm{w}$ domu właściciela [tej rzeczy] staje się $\mathrm{z}$ zasady niewolnikiem, a osoba zamierzająca dokonać spłaty szkody, musi spłacić 500.000 jeonów)". Jeon to dawna jednostka monetarna. Tłumaczenie E. Wojtasik. Tekst oryginalny za [@:] www.mtcha.com.ne.kr/korea-term/gososun/term6-8jo\%2ogumbub.htm, dostęp 23.07.2014r. 
Pomimo wielu wpływów chińskich „w sferze kultury materialnej jak i duchowej” (Ogarek-Czoj 1994: 34), które przełożyły się na powstanie późniejszego prawa koreańskiego, wierzenia i moralność a także pozostałe zasady regulujące życie codzienne opierały się na swoistym kodeksie „opartym na zgodności z prawami natury, kulcie Nieba i będącym niejako emanacją radości życia" (Ogarek-Czoj 1994: 34). Należy jednak także pamiętać, że był to czas, w którym rozpoczęto proces formalizowania rytuałów na wzór ówczesnych Chin, co przełożyło się na ukształtowanie poszczególnych procedur w taki sposób, by przypominały te funkcjonujące na kontynencie.

\subsection{Okres Trzech Królestw 삼국 三國 [sam-gug] - I p.n.e. - VII n.e.}

W wiekach I p.n.e. - VII n.e. teren Półwyspu był zdominowany przez trzy liczące się królestwa, położone odpowiednio na północy (고구려 高句麗 [Goguryeo]), na południowo-zachodniej części (백제 百濟 [Baekje]) oraz na części południowo-wschodniej (신라 新羅 [Silla]). Były to państwa, w których władzę sprawowali przedstawiciele klanu (król) bądź rada plemienna, przy czym władzę sądowniczą w zależności od rozpatrywanego państwa dzierżyła jedna osoba (minister) lub wskazani urzędnicy administracyjni. Także i w tym okresie historyczne wpływy chińskie na kulturę i piśmiennictwo się umacniały, znajdując swój wyraz także w kronikach tamtych czasów. Widoczne jest to choćby w historycznych przekazach odnoszących się do samego procesu formowania się języka koreańskiego wraz ze wszystkimi naleciałościami i pożyczkami. Lee i Ramsey (2000: 50) twierdzą wręcz, że „Silla's unification of the Korean peninsula was the most important event in the formation of Korean”. To także Silla była ostatnim z trzech koreańskich królestw, które przyjęło system pisma chińskiego (Lee i Ramsey 2000: 50).

W polityce coraz silniejszy był wpływ konfucjanizmu, uwidaczniający się w podejściu do sprawowania władzy oraz ujmowania tradycji w każdym z rozpatrywanych królestw. W Goguryeo, tworzonym przez pięć klanów $\mathrm{z}$ ich rodzimymi nazwami, doszło do przereorganizowania systemu zgodnie z zasadą „pięciu praelementów” ${ }_{2}$ - 오행 五行 [ohaeng] i zmianą nazw na zgodne z kierunkami świata oraz centrum. Podobna sytuacja zaistniała w Baekje, choć tam skonstruowano nazewnictwo w oparciu o lokalizację góra-dół. Zaadaptowano chiński system sześciu ministerstw, rang i urzędów w administracji państwowej (좌평 佐本 [jwapyeong]). W Silla istniało

2 Pięć praelementów bądź prapierwiastków to jedno z podstawowych założeń w taoizmie. Mówi ono o istnieniu pięciu głównych elementów, w oparciu o które istnieje świat z toczącym się na nim życiem. Do tych pierwiastków zalicza się wodę, drewno, ogień, ziemię i metal. Wiele z założeń taoizmu zostało wyłonionych z istniejących pierwotnie na terenach Chin wierzeń animistycznych, szamanizmu itp., by następnie zostać przeniesione i zaadaptowane do potrzeb konfucjanizmu. Por. Keller (1980: 117-123). 
pierwotnie sześć klanów, na których czele stał 마립간 麻立干 [maribgan] - władca, król, który to termin na początku VI wieku, bo w roku 503 (Lee i Ramsey 2000: 75), został zastąpiony chińskim król - 왕 王 [wang]. VI wiek to także czas wdrożenia systemu stopni urzędowych, kodeksów prawa administracyjnego, ale również system okresów panowania (Keum 2013: 30-31). W połowie wieku VII z powodzeniem wprowadzono na dwór królewski także chińskie standardy zwyczajowe, stroje, a przede wszystkim - zaadaptowano system edukacji zgodny z zaleceniami Narodowej Akademii Studiów Konfucjańskich.

Mimo względnie harmonijnego wspólistnienia szamanizmu, kultu przodków, taoizmu czy animizmu, to konfucjanizm stawał się powoli motorem zmian pozostałych sfer życia, w tym zwyczajów i obrzędów z nimi związanymi. Istniały ołtarze ku czci przodków i kaplice bóstw, np. w Goguryeo czczono Bóstwo Groty jako bóstwo rolnictwa - 수신 襚神 [susin], istniały także sanktuaria przodków królewskich - 종묘 宗廟 [jongmyo], odprawiano obrzędy ku czci Nieba przed ołtarzami na zewnątrz lub w kaplicach (ołtarz wówczas w Goguryeo nosił nazwę ołtarz państwa 국사 國社 [gugsa] a w Baekje - 원단 圓壇 [weondan]). Pod koniec istnienia Trzech Królestw znane były dzieła kanonu konfucjańskiego, filozofów chińskich, także kwestie prawne regulowane były w oparciu o standardy chińskie.

To również za czasów Silla doszło do opracowania przez konfucjanistę Seolchonga 설총 薛聰 systemu 이두 吏頭/吏讀 [Idu] (system zapisu znaków chińskich z koreańskimi elementami gramatycznymi), uznawanego za „półrodzimy język koreański” (Keum 2013: 28). Okres Trzech Królestw 삼국 三國 [sam-gug] uznać zatem można za okres, w którym pod niezwykle silnym wpływem sąsiedzkich państw chińskich uksztaltowały się koreańskie fundamenty państwowości, polityki, prawa i piśmiennictwa.

\section{3 고려 高麗 [Goryeo]-918-1392 n.e.}

Lata 918-1392 n.e. to czas, kiedy Koreą władała dynastia 고려 高麗 [Goryeo]. Głównym dokumentem, zawierającym 10 zasad precyzujących reguły panowania, był 훈요십조 訓要十條 [hun-yo-sib-jo]. Spis ten od strony prawnej wyjaśniał kwestie dziedziczenia także według prawowitej linii, abdykacji, dyscypliny utrzymywanej wśród urzędników, zasady finansowania państwa a także konieczność utrzymywania samokontroli wśród dynastii rządzącej (Keum 2013: 46-48). Testament króla Wang Geona 3 왕건 王建 zawierał również ustanowienie dwóch głównych festiwali jako obowiązkowych do odprawiania, co oznaczało także regulowanie prawa w zakresie religijnym.

W tym okresie powołano do życia odpowiednik sądu, sterowanego centralnie z ramienia rządu - 의형대 義刑臺 [Ui-hyeong-dae] jako instytucję zajmującą się sprawami prawnymi, w tym cywilnymi oraz

3 Król Wanggeon przyjął później imię Taejo 태조. 
karnymi. Rok 958 jest rokiem wprowadzenia odgórnie systemu egzaminów urzędniczych 과거 科擧 [gwageo], od wyników których zależała dalsza kariera urzędników oraz kształt tej kariery (Janasiak 2012: 33-34). Podstawową umiejętnością, wymaganą od urzędników było posługiwanie się pismem hanmun 한문 漢文. Sam termin hanmun odnosi się do znajdującej się ówcześnie $\mathrm{w}$ powszechnym stosowaniu klasycznej chińszczyźnie, w której powstawała m.in. literatura piękna czy dokumenty (por. Rurarz 2005: 208; Janasiak 2012: 217; Ogarek-Czoj 2007: 7-17). Zostaje on przyjęty za ,język urzędowy państwa koreańskiego” (Ogarek-Czoj 2003: 45), co owocuje jego powszechnością oraz rangą społeczną.

Doszło także do połączenia administracji na szczeblach centralnym i lokalnym tak, jak odbywało się to w Chinach dynastii Tang. Na szczeblu centralnym powstały tzw. trzy kancelarie, sześć rad, siedem agencji i podporządkowane im osiem jednostek, a na lokalnym - wydzielono najpierw jednostki, a potem prowincje. $\mathrm{W}$ miarę upływu czasu, władzę sądowniczą przejęły struktury administracyjne właściwe dla miejsca wystąpienia spraw w tym apelacji i odwołań. Podkreśla się jednocześnie, że pomimo wpływów zewnętrznych z Chin, państwo koreańskie „had its unique legal tradition in many aspects such as family relations and land ownership system" (Kim Kipyo 2013: 3). Wiek X pozwolił także na okrzepnięcie obecności konfucjanizmu w Korei nie tylko poprzez stosowanie prawa konfucjańskiego, ale także poprzez doprowadzenie do „instytucjonalizacji rytuałów konfucjańskich. (...) W ten sposób konfucjanizm miał dwa sile filary - system państwowych rytuałów oraz edukacji narodowej."(Keum 2013: 51).

Przytoczone już terminy konfucjańskie zamieszczone w aktach prawnych dowodzą, że samo pismo chińskie zostało przyjęte w Korei na długo przed okresem panowania dynastii Joseon. Należy jednak pamiętać, że piśmiennictwo koreańskie przechodziło w naturalny sposób kolejne etapy ewolucji. Początkowo wykształcił się styl 구결 口訣 gugyeol, z szykiem wyrazów typowym dla języka chińskiego. Uczeni w piśmie dodawali do wyrazów chińskich morfemy gramatyczne języka koreańskiego, które ułatwiały zrozumienie tekstów (An Byeong-hui, Lee Gwang-ho, 2007: 2223). Drugą odmianą był styl 이두 idu, który charakteryzował się szykiem zdania typowym dla języka koreańskiego (z orzeczeniem przesuniętym na koniec zdania). Był to typowy styl urzędowy, który był stosowany aż do końca XIX wieku. Styl ten był najbardziej "wypośrodkowany” pomiędzy gugyeol a jeszcze innym stylem, stosowanym typowo w poezji - hyangchal, ,jednak w przeciwieństwie do nich stopień wzajemnego oddziaywania elementów koreańskich i chińskich był bardziej widoczny" (Wojtasik 2009: 339).

Nawet wprowadzenie rodzimego alfabetu 한글 hangeul nie przyniosło dużych zmian $\mathrm{w}$ języku urzędowym i prawnym, gdyż $\mathrm{w}$ dalszym ciągu stosowano ideograficzne pismo chińskie. Przyczyną, dla której z tak wielkimi oporami wdrażano alfabet koreański od czasu jego opracowania i wprowadzenia w latach 1443-1446 były silne protesty warstw wyższych 
społeczeństwa, które nie chciały dopuścić do osłabienia swojej pozycji. Traktowały one wiedzę, uzyskaną $\mathrm{w}$ trakcie wieloletnich studiów nad klasyką chińską oraz różnorodnymi traktatami spisanymi w języku chińskim jako „domenę i przywilej wyłącznie najwyższych grup społecznych" (Rurarz 2005: 238). Stało to w sprzeczności z wolą króla Sejonga 세종, który postawił sobie za cel oświecenie prostej ludności koreańskiej i uproszczenia ich życia (Rurarz 2005: 239-240).

Mimo, że opracowanie i wprowadzenie do użycia alfabetu jest kolejnym krokiem milowym w rozwoju języka koreańskiego, to jednak wydaje się, że odmiana urzędowa języka koreańskiego, a co za tym idzie także warstwa języka prawa, przez długi czas pozostawała poza jego wpływem ze względu na tradycję, uwarunkowania społeczne oraz nobilitację społeczną języka chińskiego.

\section{4 조선 朝鮮 [Joseon] - lata 1392 - 1910 n.e.}

Lata 1392 - 1910 stanowią okres panowania dynastii 조선 朝鮮 [Joseon]. Urząd 사헌부 司憲府 [sa-heong-bu] od samego początku objęcia tronu przez nową dynastię ogłosił dziesięć wskazówek dla dynastii Yiª a Rada Ministrów krótko potem ogłosiła następne 22 zasady. Te ustalenia regulowały kwestie działania szkół, ale również regulowały zagadnienia rolne, kwestie administracyjne wymian i awansów urzędników. Wtedy utworzono system zbioru ziarna - 의창 義倉 [uichang], który stanowil formę zapomogi, gdyż na przednówku wydawał w odpowiednich ilościach ziarno biednym i/lub potrzebującym. Ustanowiono także wiek odpowiedni dla chłopów $\mathrm{w}$ celach pańszczyźnianych, procedurę postępowania w sprawach karnych oraz system kar więzienia i grzywien. Określono także warunki bytowania grup wędrownych i artystów. Określono zasady przystępowania przez synów szlachty (양반 兩班 [yangban] do zakonów buddyjskich. Próbowano także tworzyć podłoże dla prawa transportowego. Wprowadzono swoisty dokument tożsamości -호패 號牌 [hopae], na którym wyryte były najważniejsze dane personalne, potwierdzane przez instytucje rządowe.

Późniejszym głównym dokumentem, na którym opierał swoje panowanie król i rząd, to 경국대전 經國大典 [Gyeonggugdaejeon], stanowiący zbiór praw, ustaw ale także spis prawa zwyczajowego i rozporządzeń zarówno królewskich jak i władz miejskich. Kodeks ten powstał w roku 1484 (Kim Kipyo 2013: 3). Prawo karne w ówczesnej Korei podlegało przyjętemu z Chin Kodeksowi Karnemu Wielkich Mingów (大明律 Da Ming lü). Sprawy cywilne i karne mniejszej wagi nadal pozostawały $\mathrm{w}$ gestii urzędników administracyjnych, ale apelacjami i karnymi wyższej wagi zajmowali się gubernatorzy. Od przegranych apelacji przysługiwało prawo odwołania się do Ministra Sprawiedliwości, którego decyzja była ostateczna. Korupcje urzędników były piętnowane i rozpatrywane na prośbę ludu przez specjalnie mianowanych królewskich

4 Dynastia Yi krótko po objęciu tronu (w 1393) zmieniła nazwę na Joseon. 
śledczych. Dekrety królewskie przechodziły przez proces weryfikacji Biura Weryfikacji Królewskich Dekretów oraz Rady Stanu Dynastii Joseon. Administracja i sądownictwo były ujmowane wspólnie. Władzę wykonawczą, legislacyjną i sądową skupiał w swoich dłoniach i urzędzie król.

\subsection{Wiek XIX aż do współczesności}

Wiek XIX przyniósł względnie stabilnemu prawu koreańskiemu wielkie zmiany, gdy z chwilą opracowania Reform Gabo 갑오 개혁 [Gabo Gaehyeog] napisano także pierwszą Konstytucję koreańską. Stało się to w roku 1894, za panowania króla Gojonga, kiedy to władza sądownicza została oddzielona od administracji rządowej. Zostało to uznane za „major step towards the formulation of the modern legal system" (Kim Kipyo 2013: 5), a dokument 홍범십사조 洪範十四條 [hong beom sib sa jo] zawierający 14 zasad i norm jest uznawany za podłoże nowego współczesnego prawa koreańskiego. W roku 1895 obwieszczono ustawę powołującą do życia sądy i ostatecznie rozdzielającą władzę sądowniczą od wykonawczej, a w tym samym roku dekret królewski stworzył system adwokacki i prokuratorski.

Traktat pomiędzy Koreą a Japonią z 1905 roku, znany jako 을사조약 乙巳條約 [Eulsa joyag] lub 제 2 차 한일협약 第二次韓日協約 [je i cha hanil hyeobyag] oddawał Koreę pod nadzór Japonii, co zaowocowało przeniesieniem japońskich urzędników sądowych i sędziów by przejęli oni wszelkie kwestie związane z sądownictwem i prawem na terenie Półwyspu. Późniejsza kolonizacja Korei w latach 1910-1945 była okresem wprowadzenia japońskiego systemu prawnego w koreańską rzeczywistość prawną. Kim podkreśla, że podczas okresu okupacji japońskiej władzę pełną połączoną posiadał japoński gubernator generalny (Kim Kipyo 2013: 5), co w praktyce oznaczało, że Japończycy dążyli do wdrożenia swojego systemu w pełni na terenie okupowanej Korei. W związku z tym w terminologii prawnej $\mathrm{w}$ tamtym okresie pojawiło się mnóstwo definicji $\mathrm{z}$ prawa japońskiego.

Koniec II Wojny Światowej stanowił także koniec okupacji japońskiej. Układ sił politycznych oraz napięcia wewnętrzne doprowadziły do utworzenia się dwóch państw koreańskich na terenie Półwyspu. Od 1948 roku na południowej części powstała Republika Korei Południowej, z Konstytucją oraz ukształtowanym nowoczesnym systemem prawnym. Konstytucja jest obecnie najwyższym aktem prawnym, na którym opiera się trwający system prezydencki, kreujący proces legislacyjny, dzielący władze. Miało to swoje konsekwencje językowe - pojawiły się w tym okresie terminy niestosowane dotychczas gdyż nieistniejące w koreańskiej rzeczywistości prawnej. Takimi terminami była np. konstytucja czy prezydent. Uznaje się zatem, że współczesny system prawny w Korei „absorbed and modified necessary features of the European civil law system, Anglo-American law system and Korean customary laws altogether" (Kim Kipyo 2013:6). Przełożyło się to także na język, stosowany w dziedzinie prawa a stanowiący bezpośrednie odzwierciedlenie nie tylko procesu rozwoju prawa, ale także obecnych zmian o charakterze globalizacyjnym. Kluczowym elementem 
było także wprowadzenie na południowej części Półwyspu demokracji, o której znaczeniu dla rozwoju prawa, polityki i wiążącego się z tymi dziedzinami języka Jongryn Mo i Chaihark Hahm piszą tak: „one cannot deny that liberal democracy or the choice of liberal democratic values is one of the forces shaping human history" (2010: xv).

\section{Zapożyczenia w języku koreańskim}

Historia rozwoju prawnego i prawniczego języka koreańskiego widoczna jest zatem także w licznych zapożyczeniach, które funkcjonują $\mathrm{w}$ nim do dnia dzisiejszego. Zapożyczone elementy leksykalne oraz ich sam udział ogólny szacowany w języku koreańskim jest niezwykle trudny do ustalenia. Jedną z pierwszych prób ustalenia udziału słownictwa było skompilowanie leksykonu w postaci słownika. Na tej podstawie uznaje się obecnie, że w języku koreańskim daje się wyodrębnić około 35\% słownictwa pochodzenia rodzimego przy czym aż 6o\% jest pochodzenia chińskiego, a zapożyczeniom z innym języków przydziela się około 5\% całości (Sohn 2001: 87).

Należy zatem najpierw wyodrębnić, co rozumiane jest pod pojęciem elementu leksykalnego rodzimego a co jako pozostałe, klasyfikowane jako składowe pozostałych dwóch grup. Tak więc za element rodzimy przyjmuje się:

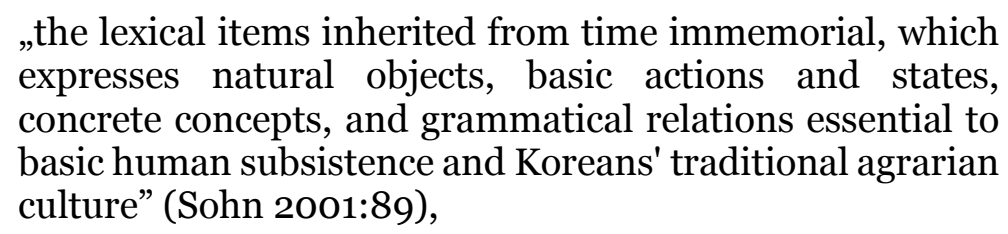

podczas, gdy element pochodzenia chińskiego i zapożyczenia z innych języków wydają się być ujmowane w jednej kategorii, z przyjętym kryterium kraju pochodzenia jako elementem rozróżniającym. Według Sohna, „both SK and loan words represent all kinds of cultural items and abstract concepts that traditional and modern civilizations have to offer" (2001: 89), choć jednak przywołuje on element uzusu jako czynnik uznania przez Koreańczyków elementów pochodzenia chińskiego „as more native-like than loan words" (2001: 89).

W języku koreańskim występują także zapożyczenia z j. chińskiego, które mimo swojego pochodzenia, nigdy nie funkcjonowały $\mathrm{w}$ języku koreańskim $\mathrm{w}$ zapisie ideogramicznym, lecz powstały na bazie morfologicznej i tak też były uwzględniane. W niektórych przypadkach ich pochodzenie jest łatwiejsze bądź trudniejsze do prześledzenia. Niektóre także odeszły w procesie inkorporacji od swojego pierwotnego znaczenia, co niewątpliwie przekłada się na możliwość precyzyjnej identyfikacji ich pochodzenia. We współczesnym języku koreańskim dają się zatem zauważyć liczne zestawienia leksykonu o tym samym znaczeniu, funkcjonującym 
jednak w różnych rejestrach i socjolektach. Jak zauważają Lee i Ramsey (2000: 135):

„Through such unimitigated borrowing from a uniform source, the Korean language is being affected today by English, as it was in the past by Literary Chinese; as a result, the Korean lexicon now contains three distinct layers of vocabulary: native, Sino-Korean, and English. These three layers give Korean, in some cases, three nearly synonymous words or expressions for what amounts to the same concept”.

\subsection{Zapożyczenia z j. chińskiego, japońskiego i angielskiego w języku koreańskiego prawa}

Koreańczycy posiłkują się hiperonimicznym terminem 외래어[oeraeo] zapożyczenie, jednak w tym samym aspekcie używają innego terminu tylko i wyłącznie na zapożyczenia z języka chińskiego. Te nazywane są terminem 한자 [hanja].

Uznaje się, że do wieku XIX, ze względów historyczno-politycznych głównym źródłem zapożyczeń w języku koreańskim był język chiński, choć jednak od 1800 roku aż do połowy wieku XX notuje się także sporo pożyczek japońskich (Lee, Ramsey 2000: 125) Strukturalnie, założyć można, że pożyczki z chińskiego są inkorporowane do języka koreańskiego w postaci rzeczowników (Lee, Ramsey 2000: 125). Możliwe jest także inne rozwiązanie morfologiczne. Za jeden $\mathrm{z}$ głównych czynników procesu zapożyczania słownictwa z języka chińskiego było korzystanie z chińskiego klasycznego i pisma chińskiego. Lee i Ramsey twierdzą, że „these SinoKorean morphemes were not loanwords at all, any more than the Latinate vocabulary in English is" (2000: 125). Wszystkie te procesy zapożyczen, prowadzące odpowiednio do zbudowania i następnie rozszerzenia posiadanego już leksykonu zauważalne są wyraźnie w języku prawa.

Należy zarazem pamiętać, że w dobie globalizacji nawet w tak silnie zdominowanym przez wpływy chińskie leksykonie terminologii prawnej i prawniczej, jakim jest zasób koreański, tam gdzie taka potrzeba zachodzi coraz częściej dochodzi do wykorzystania języka angielskiego.

Do przykładów licznych zapożyczeń w koreańskim języku prawa zaliczyć można m.in. terminy z j angielskiego, tak jak np.

\footnotetext{
아파트 kor. [apateu] - mieszkanie (ang. apartment)

소톡옵션 kor. [sotog obsyeon] - prawo pracownika do zakupu akcji po niższej cenie (ang. stock option)

110 콜센터 kor. [kol senteo] — rządowa informacja telefoniczna dla Koreańczyków (ang. call center)
} 
Emilia Wojtasik: Przyczynek do historii rozwoju ...

콘텐츠 kor. [kontencheu]-składniki (ang. contents). Ten zwrot można spotkać np. w regulacjach informatycznych, kulturalnych np. 문화 콘텐츠 kor. [munhwa kontencheu] - elementy kultury

Wiele zapożyczeń jest inkorporowanych do języka prawa przez poszczególne jej gałęzie (np. prawo handlowe, pracy czy rodzinne). Inne przykłady zapożyczeń to zarówno rzeczowniki, jak i czasowniki pochodzenia chińskiego, np.

법 원 法源 kor. [beobwon], chiń. fãyuàn- sąd jako instytucja

관하다 - 關하다 kor. [gwan-hada], chiń. guān--- wykazywać związek (z czymś)

의하다 依하다 kor. [ui-hada], chiń. ȳ̄ -- - być zgodnym z czymś/kimś, być podporząakowanym czemuś/komuś

법률 法律 kor. [beobryul], chiń. fălü- prawo (jako dziedzina)

전대하다 - 轉貸하다 kor.[jeondae hada]하다, chiń. zhuăndài -- - ponownie udostępniać/użyczać

규정 規定 kor. [gyujeong], chiń. guīdìng - ustalenia, reguły, zasady (odnoszące się do najczęściej do ilości lub/i jakości)

매수인 買受人 kor. [mae-su-in], chiń. mǎishòurén - nabywca

매도인 賣渡人 kor. [mae-do-in], chiń. măidùrén - sprzedawca

가정 家庭 kor. [gajeong], chiń. jiātíng - rodzina jako jednostka społeczna

성인 成人 kor. [seong-in], chiń. chéngrén - osoba pełnoletnia, dorosły

여 권(女權) kor. [yeogweon], chiń. nŭquán - prawa kobiet

Zauważyć można także zapożyczenia wtórne, które przeniesione zostały na koreański język prawny i prawniczy z Japonii, choć ich pierwotne pochodzenie wskazuje na źródłosłów chiński, np.

익일 翌日 kor. [igil] - rzeczownik oznaczający następny/kolejny dzień

내지 乃至 kor. [naeji] - przysłówek oznaczający „od...do” (wyrażenie czasu)

이상 以上 kor. [isang]-rzeczownik oznaczający „nadmiar” lub „ponad” 
Ze względu na bardzo duży leksykon pochodzenia chińskiego w języku prawnym oraz uwarunkowania historyczne, dawniej teksty urzędowe o charakterze formalnym (w tym i teksty ustaw) zapisywane były skryptem mieszanym. Oto przykład zapisu tego samego zdania w skrypcie mieszanym, w którym obok j. koreańskiego występują ideogramiczne zapisy leksykonu:

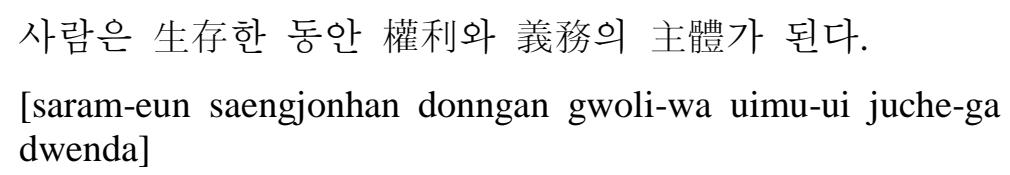

A oto to samo zdanie jedynie $\mathrm{w}$ j. koreańskim, gdzie ideogram został zastąpiony zapisem koreańskim:

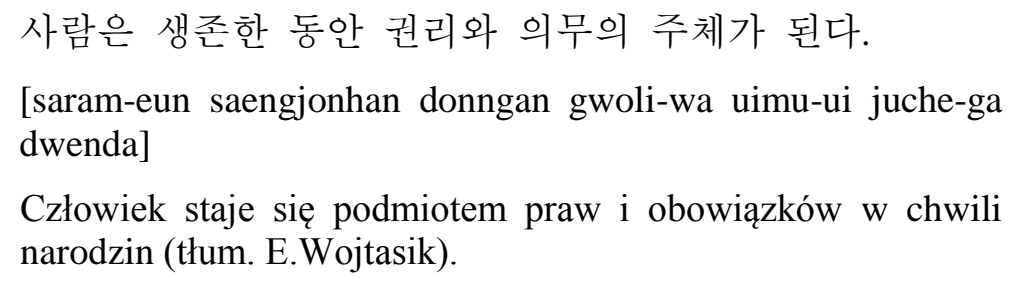

Obecnie jednak ze względu na poziom skomplikowania języka prawnego jako jednego z języków specjalistycznych, ale także i w związku z tendencją do zachowywania czystości językowej, także w Korei odchodzi się od stosowania zapisu mieszanego na rzecz zapisu jedynie w alfabecie hangeul. Przekłada się to na tekst łatwiejszy w odbiorze, ale nie niweluje to problemów towarzyszących leksyce koreańskiej jak np. polisemiczność lub homonimiczność. Należy jednakże pamiętać, że pomimo coraz bardziej powszechnego korzystania $\mathrm{z}$ alfabetu koreańskiego także $\mathrm{w}$ przypadku leksykonu zapisywanego dotychczas w ideogramach, nie jest to ani kwestia latwa ani szybka do przeprowadzenia. Ow długotrwały proces, mimo obecnej polityki będącej efektem wysiłków wielu organizacji nawołujących do czystości językowej, by wspomnieć tylko Stowarzyszenie Alfabetu 한글 학회 學會 [Hangeul Hangoe], wspierającej oczyszczanie języka ze zbędnych ideogramów (przykładem jest tu choćby przywrócenie rangi święta państwowego Dniu Hangeula i tym samym od 2013 roku dzień 9 października jest świętowany jako Dzień Alfabetu koreańskiego) jest nie tylko pracochłonny ale przede wszystkim czasochłonny i można przyjąć, że obejmie kilka następnych dziesięcioleci.

\section{Podsumowanie}

Podsumowując, język koreańskiego prawa był formowany na przestrzeni lat. $\mathrm{Na}$ terenie Półwyspu Koreańskiego, mimo, że podlegał on ciągłym transformacjom politycznym i historycznym, a co się wiąże i ciągłym wpływom języków obcych mocarstw, wykształcił się system prawny wraz 
z odpowiadającą poszczególnym zjawiskom i zasadom prawnym terminologią. Szczególnie duży wpływ miało sąsiedztwo mocarstwa chińskiego, które zaowocowało kulturowymi, literackimi, artystycznymi ale przede wszystkim prawnymi i politycznymi zmianami. Z kolei zmiany $\mathrm{w}$ prawie pociągały za sobą zmiany $\mathrm{w}$ języku, co wiązało się ze zmianami $\mathrm{w}$ kierunkach zapożyczeń. Widać to zwłaszcza $\mathrm{w}$ przypadku zestawienia leksykonu chińskiego a zaczerpniętego z innych języków, na które to zasoby Koreańczycy posiadają dwa odrębne terminy. W przypadku koreańskiego języka prawa leksykon chiński został zaimplementowany nie tylko w drodze adaptacji i modyfikacji kodeksów chińskich, ale również poprzez japoński system prawny i wiążącą się z tym terminologią. Stąd trudności w określeniu charakteru zapożyczeń z języka chińskiego w koreańskim języku prawa a więc oszacowaniu, czy są one pierwotne czy też wtórne. Przytoczone przykłady, dzięki podaniu zapisu w znakach oraz sposobie odczytania ich w języku koreańskim stanowią próbę zobrazowania tego zagadnienia. Oczywiście, w miarę upływu czasu oraz zmian na świecie, także i terminologia towarzysząca prawu ulegała zmianom ze względu na konieczność podążania za potrzebą tworzenia nowych lub dopasowywania już istniejących nazw. Stąd pojawienie się w tej warstwie językowej słownictwa z języka angielskiego. Szczególnie jest to widoczne w aktach odnoszących się do rozwijającej się technologii informatycznej, medialnej ale i w prawie wkraczającym na obszar terminologii ekonomicznej, czyli handlowym, bankowym itp. Cały proces zapożyczeń przedstawiony na tle chronologicznego ujęcia rozwoju prawa oraz języka tej dziedziny pozwala zrozumieć fenomen udziału głównie leksykonu chińskiego w ogólnej koreańskiej warstwie językowej oraz wskazać powiększający się obszar dla zapożyczeń z języka angielskiego, które to zjawisko należy osadzić silnie $\mathrm{w}$ historii Korei, jej polityki i języka a $\mathrm{w}$ obecnych czasach także $\mathrm{w}$ towarzyszącym Korei postępie cywilizacyjnym. 


\section{Bibliografia}

An, Byeong-hui., Lee, Gwang-ho. 2007. 중세국어문법론 中世國語文法論 [Teoria gramatyki średniowiecznego języka koreańskiego], Seoul: Haksa

Hahm, Pyong-Choon. 1967. The Korean political tradition and law. Seoul: Royal Asiatic Society Korea Branch

Keum, Jang-Tae. 2013. Historia koreańskiej myśli konfucjańskiej. tłum. Lee. Haesung., Barańska. D. Warszawa: Kwiaty Orientu,

Introduction to Korean Law. 2013. (ed.) Korea Legislation Research Institute, SpringerHeidelberg-New York-Dordrecht-London.

Janasiak, Ch. J., 2012. Wczesna prasa koreańska - modernizacja pisma i języka. Warszawa: Wydział Polonistyki Uniwersytetu Warszawskiego

Keller, J. (red.). 1980. Religie Azji, Afryki, Ameryki, Australii i Oceanii. Warszawa: Iskry

Kim, Kipyo. 2013. Overview. w: Introduction to Korean Law. (ed.) Korea Legislation Research Institute, Springer Heidelberg-New York-DordrechtLondon.

Lee, Iksop., Ramsey, R. S. 2000. The Korean Language, Seoul: SUNY Press,.

Matulewska, A. 2007. Lingua Legis in Translation. Frankfurt am Main: Peter Lang $\mathrm{GmbH}$.

Mo, Jongryn., Brady, D.W. (ed.). 2010. The rule of Law in South Korea. Stanford: Hoover Institution Press, Stanford University.

Ogarek-Czoj, H., 1984. Tonghak - nauka Wschodu. Warszawa: Iskry

Ogarek-Czoj, H., 2003. Klasyczna literatura koreańska. Warszawa: DIALOG

Ogarek-Czoj, H., 2007. Literatura koreańska XX wieku. Warszawa: DIALOG

Rurarz, J.P., 2009. Historia Korei. Warszawa: DIALOG

Rybicka-Nowacka, H., 1973. Rzeczowniki zapożyczone z łaciny w j. polskim XVII wieku. Wrocław: Ossolineum

Sohn, Ho-Min. 1999, 2001. The Korean Language. London: Cambridge University Press.

[@:] www. mtcha.com.ne.kr/korea-term/gososun/term6-8jo\%2ogumbub.html

Słownik Koreańsko-Koreański: [@:] http://krdic.naver.com

Wojtasik, E. 2009. 한자/사자/고사성어 (Hanja/Saja/Gosa Seongo) powiedzenia i zwroty pochodzenia chińskiego w języku koreańskim uwarunkowania historyczno-kulturowe. w: Wokót słów i znaczeń. T III. Z zagadnień leksykalno-semantycznych. (red.) Milewska., B., Rzedzicka, S. Gdańsk: Wydawnictwo Uniwersytetu Gdańskiego 